\title{
Evidence for in vivo Interactions between Neuropeptide $Y$-related Peptides and $\sigma$ Receptors in the Mouse Hippocampal Formation
}

\author{
Pascale Bouchard, ${ }^{1,2}$ Yvan Dumont, ${ }^{1}$ Alain Fournier, ${ }^{4}$ Serge St.-Pierre, ${ }^{4}$ and Rémi Quirion ${ }^{1,2,3}$ \\ 'Douglas Hospital Research Center, Verdun, Québec, Canada H4H 1R3, ${ }^{2}$ Department of Neurology and Neurosurgery \\ and ${ }^{3}$ Department of Psychiatry, McGill University, Montréal, Québec, Canada, and ${ }^{4}$ nstitut National de la Recherche \\ Scientifique-Santé, Université du Québec, Pointe-Claire, Québec, Canada H9R 1G6
}

Recently, it was proposed that neuropeptide Y (NPY) and peptide YY (PYY) could act as endogenous ligands for $\sigma$ binding sites, as both NPY and PYY competed with high affinity (nanomolar) for ${ }^{3} \mathrm{H}-(+)$ SKF 10,047 binding sites in rat brain membrane homogenates (Roman et al., 1989). However, various laboratories failed to replicate these in vitro findings. In order to clarify this apparent discrepancy and investigate further possible interactions between NPY and $\sigma$ related sites, we evaluated the effects of NPY, PYY and homologs, as well as nonrelated peptides, on in vivo ${ }^{3} \mathrm{H}$ $(+)$ SKF 10,047 binding parameters in the mouse hippocampal formation. As expected, haloperidol $(2 \mathrm{mg} / \mathrm{kg}$ ), a prototypical $\sigma$ receptor ligand, competed for $90 \%$ of in vivo hippocampal labeling observed following a peripheral intravenous injection of ${ }^{3} \mathrm{H}-(+)$ SKF 10,047 . Intracerebroventricular injections of 300-3000 pmol of either NPY, PYY, NPY ${ }_{2-36}$, or the $Y_{1}$ agonist Leu ${ }^{31}$,Pro ${ }^{34}$-NPY inhibited significant proportions (17-35\%) of haloperidol-sensitive in vivo ${ }^{3} \mathrm{H}-(+)$ SKF 10,047 hippocampal labeling. However, a $Y_{2}$ receptor agonist, NPY ${ }_{13-36}$, and nonrelated peptides such as neurotensin and vasoactive intestinal polypeptide, as well as adrenalin, failed to alter in vivo ${ }^{3} \mathrm{H}-(+)$ SKF 10,047 hippocampal binding. It thus appears that NPY, PYY, and a selective $Y_{1}$ agonist can interact in a concentration-dependant manner, with in vivo ${ }^{3} \mathrm{H}-(+)$ SKF 10,047 labeling in the mouse hippocampal formation. This effect demonstrates selectivity as a $Y_{2}$ agonist, unrelated peptides, and adrenalin failed to alter in vivo $\sigma$ labeling. This in vivo interaction may be relevant to some of the respective biological actions of NPY and $\sigma$-related molecules.

[Key words: neuropeptide $Y$, peptide $Y Y$, sigma receptors, N-ally/normetazocine (NANM or SKF 10,047), hippocampus, in vivo binding]

The existence of sigma $(\sigma)$ receptor binding sites in the brain has generated much interest over the past few years likely because of their possible involvement in psychosis-related behaviors (for recent reviews, see Deutsch et al., 1988; Junien and

\footnotetext{
Received Nov. 2, 1992; revised Feb. 1, 1993; accepted Mar. 23, 1993.

This research project is supported by Program Grant 38 from the Medical Research Council of Canada, and a studentship award from Jouveinal Laboratories (Fresnes, France) to P.B. R.Q. is a Cherchcur-Boursicr "mćritc cxceptionnel" and A.F. is a Chercheur Boursier from the "Fonds de la Recherche en Santé du Québec."

Correspondence should be addressed to Dr. Rémi Quirion, Douglas Hospital Research Center, 6875 Boulevard LaSalle, Verdun, Québec, Canada H4H 1 R3.

Copyright (C) 1993 Society for Neuroscience $0270-6474 / 93 / 133926-06 \$ 05.00 / 0$
}

Leonard, 1989; Snyder and Largent, 1989; Chavkin, 1990; Musacchio, 1990; Walker et al., 1990; Ferris et al., 1991; Itzhak and Stein, 1991a; Su, 1991). This assumption is mostly based on the fact that high densities of $\sigma$ binding sites are found in various limbic structures, including the hippocampus (Gundlach et al., 1986; Contreras et al., 1987b; McLean and Weber, 1988), and to the high affinity of some neuroleptics (e.g., haloperidol and remoxipride, but not sulpiride) for $\sigma$ sites ( $\mathrm{Su}, 1982$, 1991; Tam and Cook, 1984; Taylor and Dekleva, 1987). This suggested the possible development of a new class of $\sigma$-related antipsychotic drugs devoid of dopaminergic activity (Su, 1986; Taylor and Dekleva, 1987; Snyder and Largent, 1989). Additional support for this hypothesis came from observations suggesting that certain $\sigma$ drugs such as $N$-allylnormetazocine (NANM or SKF 10,047) induced hallucinations in man (Keats and Telford, 1964) and delirium in the chronic spinal dog (Martin et al., 1976; Vaupel, 1983), although the genuine $\sigma$ nature of these effects remains to be fully established (Quirion et al., 1987; Walker et al., 1990).

The abundance and discrete distribution of $\sigma$ sites in the mammalian brain may also reveal the possible existence of endogenous $\sigma$-related ligands. Early on, few groups (Quirion et al., 1984; Su et al., 1986; Contreras et al., 1987a; Su and Vaupel, 1988; Zhang et al., 1988; Connor and Chavkin, 1991, 1992) reported on the possible isolation of such molecules, although their purification to homogeneity still remains to be accomplished. Thus, the report by Roman et al. (1989) suggesting that peptides of the pancreatic polypeptide family, namely, neuropeptide Y (NPY) and polypeptide YY (PYY), were able to compete with high affinities for in vitro ${ }^{3} \mathrm{H}-(+)$ SKF $10,047 / \sigma$ binding sites generated tremendous interests. However, it has been difficult to replicate these findings using well-established in vitro membrane binding assays (Quirion et al., 1991; Tam and Mitchell, 1991).

On the other hand, evidence has recently accumulated supporting the existence of interactions between NPY and $\sigma$-related systems, in vivo. For example, Monnet et al. (1990a,b, 1992ac) have shown that both NPY and $\sigma$ agonists, in a haloperidolsensitive manner, are able to potentiate $N$-methyl-D-aspartate (NMDA)-induced firing in the pyramidal CA3 subfield of the hippocampal formation (but see McQuiston and Colmers, 1991; Connick et al., 1992). Additionally, NPY and a selective $\sigma$ ligand, JO 1784, can decrease intestinal transport apparently via haloperidol-sensitive $\sigma$ receptors (Rivière et al., 1990). Moreover, it appears that NPY and homologs, as well as various $\sigma$ ligands, are able to potentiate NMDA-induced ${ }^{3} \mathrm{H}$-noradrenaline release in rat hippocampal slices (Monnet et al., 1991; Ro- 
man et al., 1991). Accordingly, we decided to investigate further possible interactions between NPY-related peptides and $\sigma$ receptor sites in the mouse hippocampus using an in vivo binding approach; the hippocampal formation was chosen as this region is most enriched with both $\sigma$ - (Gundlach et al., 1986; Contreras et al., 1987b; McLean and Weber, 1988; Weissman et al., 1988, 1990) and NPY (Martel et al., 1986, 1990a; Lynch et al., 1989; Dumont et al., 1990, 1992,1993) receptors. Our results suggest that NPY, PYY, and a selective agonist of the $Y_{1}$ receptor subtype can interact with a certain proportion of in vivo ${ }^{3} \mathrm{H}-(+)$ SKF 10,047 labeling in the mouse hippocampus.

\section{Materials and Methods}

Materials. ${ }^{3} \mathrm{H}-(+) \mathrm{SKF}$ 10,047 $(53 \mathrm{Ci} / \mathrm{mmol}$; Comission Energie Atomique, Saclay, France) was provided by the Institut de Recherches Jouveinal, Fresnes, France. All NPY-related peptides as well as neurotensin and vasoactive intestinal polypeptide (VIP) were synthesized in our laboratories as described earlier (St.-Pierre et al., 1981; Martel et al., 1990b). Adrenalin, haloperidol, trizma base (Tris), $\mathrm{NaCl}$, and polyethyleneimine (PEI) were purchased from Sigma Chemicals (St. Louis, MI). MK-801 was from Research Biochemicals Inc. (Natick, MA), ether and GF/B Whatman filters were obtained from Fisher (Montréal, Canada), and Ecolite TM + was purchased from ICN Biochemicals (Montréal, Canada).

Animals. Male CD-1 mice (20-24 gm) were purchased from Charles River (St.-Constant, Québec, Canada). Animals were housed in a temperature- and humidity-controlled room on a $12 \mathrm{hr}: 12 \mathrm{hr}$ light/dark cycle, and were fed ad libitum with standard laboratory chow and tap water. They were kept under these conditions for at least $24 \mathrm{hr}$ prior to the experiment. Animal care was according to protocols and guidelines approved by McGill University and the Canadian Council for Animal Care.

Binding experiments. For in vivo binding experiments, mice were injected at time $(t)-0$ with $2 \mathrm{mg} / \mathrm{kg}$ haloperidol $(100 \mu \mathrm{l}$, i.p.), MK$801(0.05,0.1,0.2$, or $0.5 \mathrm{mg} / \mathrm{kg} 100 \mu$ l. i.p. $)$, or saline $(0.9 \% \mathrm{NaCl}, 100$ $\mu \mathrm{l}$, i.p.) in order to determine the proportion of in vivo ${ }^{3} \mathrm{H}-(+) \mathrm{SKF} 10,047$ labeling that can be related to $\sigma$ sites. At $t=15 \mathrm{~min}$, under light ether anesthesia, animals received either a peptide injection $(3 \mu$ l, i.c.v.) or saline $(3 \mu$ l, i.c.v.). Fifteen minutes later $(t=30 \mathrm{~min})$, animals were injected in the tail vein with $5 \mu \mathrm{Ci}$ of ${ }^{3} \mathrm{H}-(+)$ SKF $10,047(200 \mu$ l, i.v. $)$. Animals were killed by dislocation at $t=60 \mathrm{~min}$. Brains were then rapidly removed and hippocampi were dissected on ice and immediately homogenized in $1 \mathrm{ml}$ of ice-cold buffer (Tris- $\mathrm{HCl} 5 \mathrm{~mm}, \mathrm{pH} 7.4$ at $4^{\circ} \mathrm{C}$ ) using a Teflon/glass Potter-Elvehjem probes (12 strokes). Immediately thereafter, $1 \mathrm{ml}$ of ice-cold Tris-HCl buffer was added to this homogenate before filtration of $1.5 \mathrm{ml}$ of this preparation through three $\mathrm{GF} /$ B glass filters (pretreated for at least $24 \mathrm{hr}$ in buffer containing $0.05 \%$ PEI) under vacuum using a 12-hole Millipore CAT apparatus. Filters were then washed twice with $5 \mathrm{ml}$ of ice-cold incubation buffer and then placed in vials containing $5 \mathrm{ml}$ of Ecolite TM+ scintillation cocktail. Radioactivity was determined using a Beckman LS1800 counter with $40 \%$ efficiency. The remaining $0.5 \mathrm{ml}$ of the homogenate was kept for protein determination (Lowry et al., 1951). Statistical analyses were performed using the Student's $t$ test, $p<0.05$ being considered statistically significant.

\section{Results}

In preliminary experiments we failed to obtain evidence for in vitro interactions between NPY, PYY, and ${ }^{3} \mathrm{H}-(+)$ SKF $10,047 /$ $\sigma$ sites as the two peptides, in concentrations ranging from $10^{-11}$ to $10^{-6} \mathbf{M}$, did not compete for in vitro ${ }^{3} \mathrm{H}-(+)$ SKF 10,047 binding in mouse brain membrane preparations. These findings confirmed data obtained earlier in the rat brain (Quirion et al., 1991; Tam and Mitchell, 1991).

In vivo ${ }^{3} \mathrm{H}-(+) S K F 10,047$ binding in the mouse hippocampus An equivalent of approximately $15 \mathrm{fmol} / \mathrm{mg}$ of protein was detected in the mouse hippocampus following an injection in the tail vein of $5 \mu \mathrm{Ci}$ of the $\sigma$ ligand ${ }^{3} \mathrm{H}-(+) \mathrm{SKF} 10,047$. In the

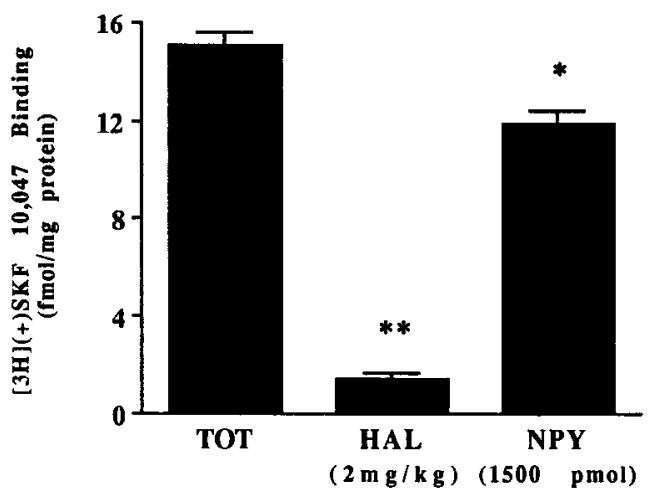

Figure 1. ${ }^{3} \mathrm{H}-(+)$ SKF 10,047-related radioactive material present in the mouse hippocampal formation following a peripheral intravenous injection ( $5 \mu \mathrm{Ci}$ per $200 \mu \mathrm{l}$, tail vein; total $n=51)$. ${ }^{3} \mathrm{H}-(+)$ SKF 10,047 binding is most likely related to $\sigma$ sites as haloperidol $(2 \mathrm{mg} / \mathrm{kg}$, i.p.; $n=11$ ) almost completely inhibited $(90 \%)$ labeling in the mouse hippocampus. Similarly, although to a lesser extent, intracerebroventricular injections of NPY (1500 pmol; $n=23)$ significantly inhibited hippocampal ${ }^{3} \mathrm{H}-(+)$ SKF 10,047 labeling. ${ }^{*}, p<0.005 ;{ }^{* *}, p<0.001$.

presence of haloperidol ( $2 \mathrm{mg} / \mathrm{kg}$, i.p.) residual ${ }^{3} \mathrm{H}-(+)$ SKF 10,047 hippocampal binding accounted for only $1.48 \mathrm{fmol} / \mathrm{mg}$ of protein, revealing that approximately $90 \%$ (13.52 fmol $/ \mathrm{mg}$ protein) of total labeling was sensitive to the prototypical $\sigma$ ligand (Fig. 1). The NMDA/phencyclidine (PCP) receptor ligand MK-801 did not inhibit the specific ${ }^{3} \mathrm{H}-(+)$ SKF 10,047 labeling in the mouse hippocampal formation at intraperitoneal doses of 0.05 , $0.1,0.2$, and $0.5 \mathrm{mg} / \mathrm{kg}(n=26$; data not shown).

\section{Competition by NPY-related peptides}

As shown in Figure 3, NPY, NPY ${ }_{2-36}$, Leu $^{31}$, Pro $^{34}-N P Y$ (a purported $Y_{1}$ agonist; Fuhlendorff et al., 1990), and PYY were able to displace approximately one-third of specific in vivo ${ }^{3} \mathrm{H}-(+) \mathrm{SKF}$ 10,047 labeling in the mouse hippocampus. The fragment $\mathrm{NPY}_{13-}$ ${ }_{36}$ (a $Y_{2}$ agonist; Wahlestedt et al., 1986) and the analog desamido-NPY (NPY-OH) were inactive. As shown in Figure 2, various doses of NPY $(300,600,1000,1500$, and 3000 pmol, i.c.v.) demonstrated that this peptide inhibited the in vivo hippocampal labeling of ${ }^{3} \mathrm{H}-(+)$ SKF 10,047 in a dose-related manner. The minimal effective dose appears to be in the range of 600 pmol while a maximal effect was observed at $1500 \mathrm{pmol}$, a higher dose of NPY (3000 pmol) failing to produce a greater effect (Fig. 2).

The respective potency of various NPY-related peptides to inhibit in vivo ${ }^{3} \mathrm{H}-(+) \mathrm{SKF} 10,047$ labeling in the mouse hippocampus is shown in Figure 3. At doses of 1500 and 3000 pmol, the homolog PYY most potently inhibited specific ${ }^{3} \mathrm{H}$ (+)SKF 10,047 labeling, its effects being apparently even greater than that of NPY. In contrast, NPY-OH failed to inhibit ${ }^{3} \mathrm{H}$ (+)SKF 10,047 labeling (Fig. 3A), as expected for this biologically inactive analog (Wahlestedt et al., 1986).

The fragment $\mathrm{NPY}_{2-36}$ was able to mimic the effect of the full NPY molecule on ${ }^{3} \mathrm{H}-(+)$ SKF 10,047 labeling (Fig. 3B). However, a shorter C-terminal fragment, $N Y_{13-36}$, a purported $Y_{2}$ agonist (Wahlestedt et al., 1986), failed to alter ${ }^{3} \mathrm{H}-(+)$ SKF 10,047 labeling at $1500 \mathrm{pmol}$ (Fig. 3B). On the other hand, the $Y_{1}$ agonist $\mathrm{Leu}^{31}, \mathrm{Pro}^{34}-\mathrm{NPY}$, was the most potent competitor of in vivo ${ }^{3} \mathrm{H}-(+)$ SKF 10,047 labeling tested in this study, with a profile similar to that of NPY, namely, a dose of $1500 \mathrm{pmol}$ inducing a greater effect than that of 3000 pmol (Figs. 2, 3B). 


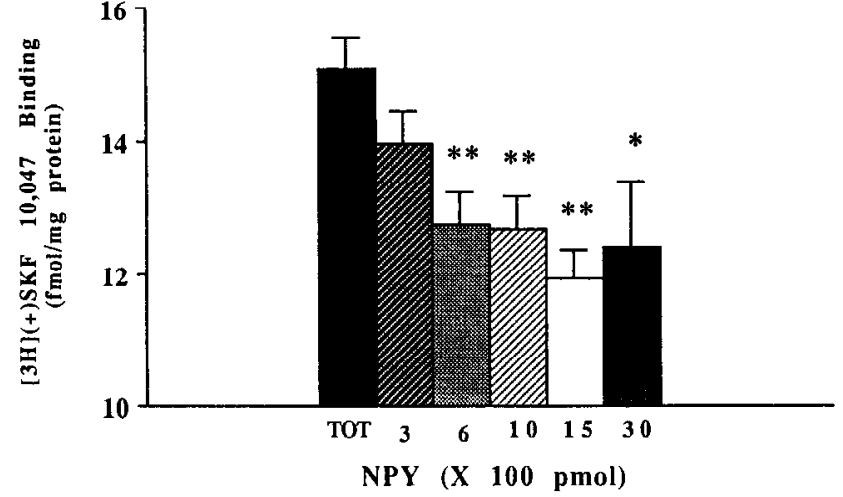

Figure 2. Dose dependency demonstration of the effect of NPY on in vivo ${ }^{3} \mathrm{H}-(+)$ SKF 10,047 labeling of the mouse hippocampal formation. Intracerebroventricular injections of increasing doses of NPY significantly inhibited in vivo ${ }^{3} \mathrm{H}-(+) \mathrm{SKF} 10,047$ labeling (total $\left.n=51\right)$ with a minimally effective dose in the range of $600 \mathrm{pmol}(n=23)$; a lower dose (300 pmol; $n=25$ ) inhibited binding to a nonsignificant extent; $1000 \mathrm{pmol}(n=23)$ produced a greater inhibition than that of $600 \mathrm{pmol}$, while maximal effectiveness was observed at $1500 \mathrm{pmol}(n=23)$, with 3000 pmol $(n=11)$ being somewhat less effective. ${ }^{*}, p<0.05 ;{ }^{* *}, p<$ 0.005 .

\section{Specificity of NPY for in vivo hippocampal ${ }^{3} H-(+) S K F$} 10.047 labeling

As a means to assess the specificity of the effect of NPY and related analogs for in vivo ${ }^{3} \mathrm{H}-(+)$ SKF 10,047 labeling, we investigated next the effects of two other classes of peptides, namely, neurotensin $(1500 \mathrm{pmol})$ and VIP (1500 pmol), and of the well-known vasoconstrictor/neurotransmitter adrenalin (1500 and $3000 \mathrm{pmol}$ ). These three molecules failed to alter in vivo ${ }^{3} \mathrm{H}-(+)$ SKF 10,047 labeling in the mouse hippocampus at doses tested here (Fig. 4).

\section{Discussion}

The present study demonstrates that (1) NPY and its homolog PYY dose-dependently inhibited the in vivo binding of the prototypical $\sigma$ ligand ${ }^{3} \mathrm{H}-(+)$ SKF 10,047 in the mouse hippocampal formation; (2) a similar effect is also seen with a $Y_{1}\left(\right.$ Leu $^{31}$, Pro $^{34}$ NPY) but not a $Y_{2}\left(N P Y_{13-36}\right)$ receptor agonist, suggesting receptor subtype specificity; (3) a biologically inactive NPY analog, NPY$\mathrm{OH}$, failed to alter in vivo ${ }^{3} \mathrm{H}-(+) \mathrm{SKF} 10,047$ labeling; and (4) other biologically active polypeptides such as neurotensin and VIP, which are known to induce various cerebrovascular and neuronal effects (Rioux et al., 1981; Wilson et al., 1981), and adrenalin failed to modulate in vivo ${ }^{3} \mathrm{H}-(+)$ SKF 10,047 labeling, demonstrating the specificity of the interactions between certain NPY-related peptides and in vivo ${ }^{3} \mathrm{H}-(+) \mathrm{SKF} 10,047$ binding in the mouse hippocampus.

The hippocampal labeling observed following an intravenous injection of ${ }^{3} \mathrm{H}-(+)$ SKF 10,047 is very likely representing binding to $\sigma$ sites that are most abundant in this region (Largent et al., 1986; Contreras et al., 1987b; Weissman et al., 1990). While $(+)$ SKF 10,047 can bind with relatively high affinities to both PCP and $\sigma$ sites (Su, 1982; Largent et al., 1986; Quirion et al., 1987; McCann et al., 1989), only the $\sigma$ component is sensitive to haloperidol (Su, 1982; Tam and Cook, 1984). Moreover, four different doses $(0.05,0.1,0.2$, and $0.5 \mathrm{mg} / \mathrm{kg}$, i.p.; $n=26)$ of the high-affinity NMDA/PCP receptor ligand MK-801 (Loo et al., 1987) did not reduce the specific in vivo ${ }^{3} \mathrm{H}-(+)$ SKF 10,047 labeling in the mouse hippocampus. Thus, the high sensitivity

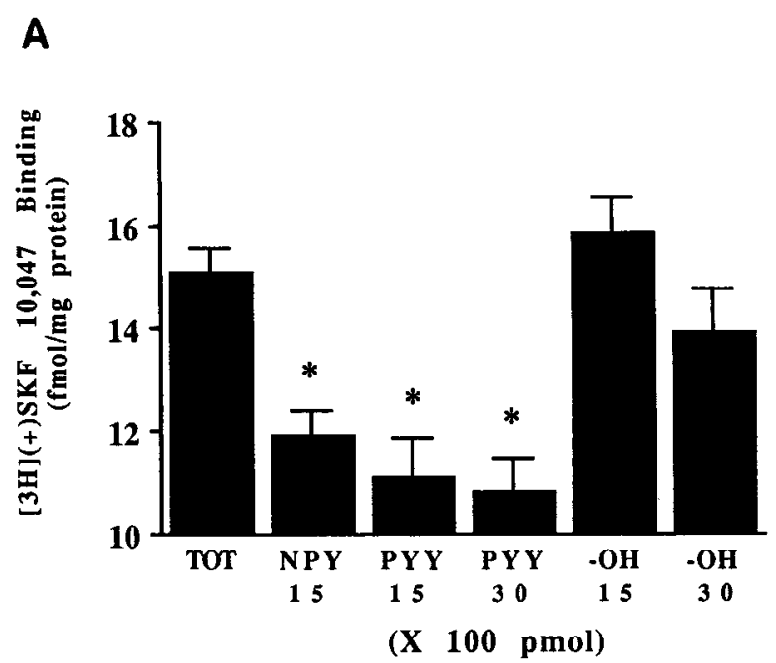

B

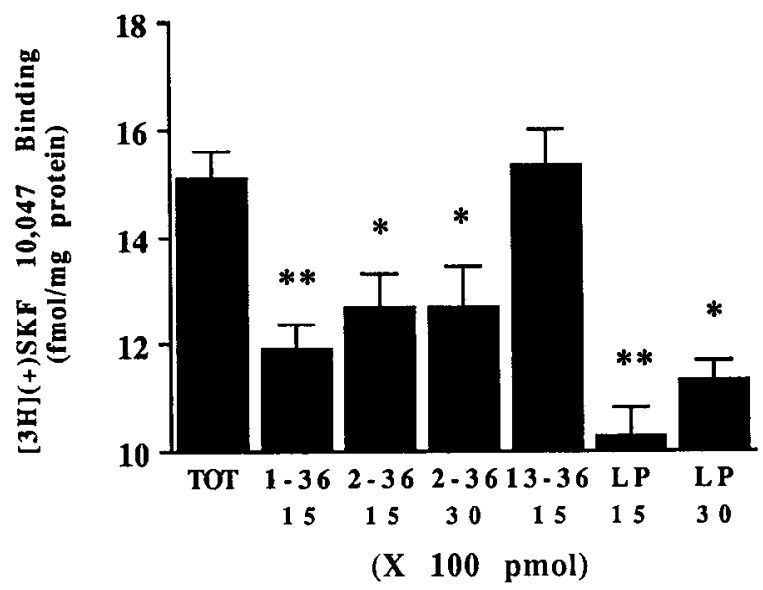

Figure 3. A, Comparative potencies of NPY, PYY, and NPY-OH to inhibit in vivo ${ }^{3} \mathrm{H}-(+)$ SKF 10,047 labeling (total $\left.n=51\right)$ in the mouse hippocampal formation. PYY at $1500 \mathrm{pmol}(n=13)$ and $3000 \mathrm{pmol}$ $(n=8)$ was slightly more potent than NPY at 1500 pmol $(n=23)$ to inhibit labeling, while NPY-OH at 1500 pmol $(n-7)$ and $3000 \mathrm{pmol}$ $(n=13)$ failed to produce any significant effect. ${ }^{*}, p<0.005$. $B$, Comparative potencies of $\mathrm{NPY}_{\mathrm{t}-36}, \mathrm{C}$-terminal fragments $\mathrm{NPY}_{2-36}$ and $\mathrm{NPY}_{13-}$ ${ }_{36}$ ), and the analog Leu ${ }^{31}, \mathrm{Pro}^{34}-\mathrm{NPY}(L P)$ to inhibit in vivo ${ }^{3} \mathrm{H}-(+) \mathrm{SKF}$ 10,047 labeling (total $n=51$ ) in the mouse hippocampal formation. $\mathrm{NPY}_{2-36}$ at $1500 \mathrm{pmol}(n=20)$ and $3000 \mathrm{pmol}(n=10)$ significantly inhibited ${ }^{3} \mathrm{H}-(+)$ SKF 10,047 binding albeit to a lower extent than the full peptide, at $1500 \mathrm{pmol}(n=23)$. A prototypical $\mathrm{Y}_{2}$ fragment, $\mathrm{NPY}_{13-}$ ${ }_{36}(1500 \mathrm{pmol}, n=14)$, failed to exert any effect on ${ }^{3} \mathrm{H}-(+) \mathrm{SKF} 10,047$ labeling, while the $\mathrm{Y}_{1}$ agonist $\mathrm{Leu}^{31}$, $\mathrm{Pro}^{34}$-NPY potently competed for labeling at $1500 \mathrm{pmol}(n=14)$ and $3000 \mathrm{pmol}(n=7){ }^{*}, p<0.05$; **, $p<0.005$.

of in vivo hippocampal ${ }^{3} \mathrm{H}-(+)$ SKF 10,047 labeling to haloperidol, together with the ineffectiveness of MK-801 to inhibit the specific ${ }^{3} \mathrm{H}-(+)$ SKF 10,047 labeling in the mouse hippocampus in vivo, confirms the $\sigma$ nature of the related sites. Our results also extend previously reported in vivo ${ }^{3} \mathrm{H}-(+) \mathrm{SKF} 10,047 / \sigma$ related binding data (Ferris et al., 1988; Tam et al., 1988; Weissman et al., 1990). However, it is unclear if, under the present assay conditions, in vivo ${ }^{3} \mathrm{H}-(+)$ SKF 10,047 labeling represents binding to more than one subtype of $\sigma$ site. Recently, evidence has been obtained to support the existence of at least two classes $(\sigma 1$ and $\sigma 2)$ of $\sigma$ sites (Hellewell and Bowen, 1990; Itzhak and Stein, 1991a,b; Itzhak et al., 1991; Su et al., 1991; Quirion et 
al., 1992; Vilner and Bowen, 1992). These two putative subtypes demonstrate similar affinity for haloperidol, while (+)SKF 10,047 apparently preferentially labels the $\sigma 1$ sites (Hellewell and Bowen., 1990; Itzhak and Stein, 1991 b; Itzhak et al., 1991; Su et al., 1991; Quirion et al., 1992; Vilner and Bowen, 1992), although it can also possibly bind to the $\sigma 2$ site at concentrations comparable to that used in the present study $(5 \mu \mathrm{Ci}, \mathrm{i}$.v.). Additional experiments using other 0 -related radioligands such as ${ }^{3} \mathrm{H}$ $(+)$ pentazocine $(\sigma 1)$ and ${ }^{3} \mathrm{H}-\mathrm{DTG}$ (in presence of a saturating concentration of dextrallorphan) for $\alpha 2$ sites (DiPaolo et al., 1991; Bowen et al., 1992) will be required to clarify this issue. Already, in a series of preliminary experiments, we attempted to investigate the in vivo labeling of the mouse hippocampus following intravenous injections of either ${ }^{3} \mathrm{H}-\mathrm{DTG}$ or ${ }^{3} \mathrm{H}$ $(+)$ pentazocine. However, in contrast to ${ }^{3} \mathrm{H}-(+)$ SKF 10,047 , the amounts of radioactivity recovered in the hippocampal formation using either probe were too low to permit adequate pharmacological characterization (150-500 dpm per $5 \mu \mathrm{Ci})$. Moreover, in vivo ${ }^{3} \mathrm{H}-\mathrm{DTG}$ labeling was apparently mostly restricted to ventricular epithelia as revealed by in vivo autoradiography (P. Bouchard, Y. Dumont, A. Fournier, S. St.-Pierre, and R. Quirion, unpublished observations). Thus, it appears that other radioligands will have to be developed in order to investigate adequately the in vivo binding profiles of $o 1$ and $o 2$ sites in the mouse brain.

The extent of the competition seen between ${ }^{3} \mathrm{H}-(+)$ SKF 10,047 and NPY-related peptides following their respective in vivo injections also supports the possible labeling by the radioligand of two classes of $\sigma$ site. While haloperidol competed for up to $90 \%$ of ${ }^{3} \mathrm{H}-(+)$ SKF 10,047 labeling in the mouse hippocampus, intracerebroventricular injections of NPY and its homologs inhibited approximately one-third of the labeling, suggesting that ${ }^{3} \mathrm{H}-(+)$ SKF 10,047 could interact with subtypes of $\sigma$-sites, only one being accessible to NPY and related peptides.

The precise nature of in vivo interactions between ${ }^{3} \mathrm{H}-(+) \mathrm{SKF}$ 10,047 labeling and NPY remains speculative. It clearly displays specificity as two other families of well-known peptides, neurotensin and VIP, failed to alter in vivo ${ }^{3} \mathrm{H}-(+)$ SKF 10,047 binding under our assay conditions. Similarly, the effects of NPYrelated peptides are unlikely to be related only to changes in cerebral blood flow as adrenalin, a potent constrictor of the cerebral vasculature, as well as neurotensin and VIP, two peptides with potent cerebrovascular activities (Rioux et al., 1981; Wilson et al., 1981), failed to modify in vivo ${ }^{3} \mathrm{H}-(+) \mathrm{SKF} 10,047$ labeling of the mouse hippocampus.

We (Quirion et al., 1991) and others (Tam and Mitchell, 1991) were unable to obtain clear evidence for the existence of in vitro receptor binding interactions between a variety of $\sigma$ - and NPYrelated molecules. Interestingly, various peptidase inhibitors arc generally used in in vitro binding assays to insure the integrity of NPY peptides used either as radioligands and/or competitors (Lynch et al., 1989; Martel et al., 1990a,b; Quirion et al., 1991). Could it be that an endogenously generated NPY metabolite is able to act as a $\sigma$ ligand in vivo? While clear evidence is currently lacking to support this hypothesis, Contreras et al. (1987a) proposed the existence of endogenous $\sigma$ ligands of peptidergic nature. It is thus of interest that only certain NPY-related peptides were able to modulate the in vivo labeling of ${ }^{3} \mathrm{H}-(+) \mathrm{SKF} 10,047$ in the mouse hippocampus. Both NPY-OH and the relatively selective $Y_{2}$ agonist $N P Y_{13-36}$ (Wahlestedt et al., 1986) failed to demonstrate any activity in this assay. In contrast NPY, its homolog PYY, the fragment $\mathrm{NPY}_{2-36}$, and the $\mathrm{Y}_{1}$ agonist

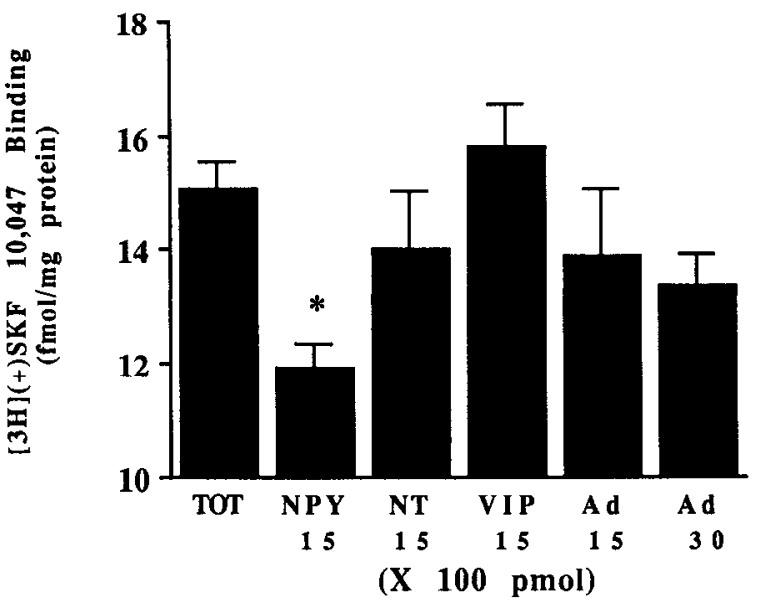

Figure 4. Comparative effects of NPY $(n=23)$, ncurotensin $(N T ; 1500$ pmol, $n=9)$, VIP (1500 pmol, $n=17)$, and the catecholamine adrenalin (Ad; 1500 pmol, $n=7 ; 3000$ pmol, $n=11$ ) on in vivo ${ }^{3} \mathrm{H}-(+)$ SKF 10,047 labeling (total $n=51$ ) in the mouse hippocampal formation. At this concentration, it is evident that only NPY significantly interacted with in vivo ${ }^{3} \mathrm{H}-(+)$ SKF 10,047 labeling. *, $p<0.005$.

Leu $^{31}$, Pro $^{34}$-NPY (Fuhlendorf et al., 1990) behaved as potent competitors. Taken together, these data may suggest that if a metabolite(s) of NPY is responsible for the inhibition of ${ }^{3} \mathrm{H}$ (+)SKF 10,047/ $\sigma$ labeling, it could be an N-terminal fragment likely containing amino acid residue located between positions 2 and 13. Alternatively, it could be that NPY and some of its related peptides can induce the release of a yet to be characterized endogenous $\sigma$ ligand that could then inhibit the in vivo binding of ${ }^{3} \mathrm{H}-(+)$ SKF 10,047 . Recent data by Connor and Chavkin $(1991,1992)$ are especially interesting in that regard as they provide evidence for the existence of endogenous $\sigma \mathrm{li}$ gands in the hippocampus. It is also possible that NPY-related peptides, by modulating signal transduction activity, could alter in vivo ${ }^{3} \mathrm{H}-(+)$ SKF 10,047/ $\mathrm{labeling}$. These various possibilities are currently under investigation.

The ligand selectivity profile observed here for NPY and its homologs is most reminiscent of a $\mathrm{Y}_{1}$-like profile (Wahlestedt et al., 1986, 1990; Fuhlendorff et al., 1990; Quirion et al., 1990; Dumont et al., 1992) on the basis of the potent activity of the $Y_{1}$ analog Leu ${ }^{31}$, Pro $^{34}-\mathrm{NPY}$ and the ineffectiveness of NPY ${ }_{13-36}$, a $Y_{2}$ agonist (Wahlestedt et al., 1986), to modulate hippocampal in vivo ${ }^{3} \mathrm{H}-(+)$ SKF 10,047 labeling. The high potency of $\mathrm{PYY}$ in this assay would also exclude an interaction with the newly characterized $\mathrm{Y}_{3}$ receptor subtype as PYY was reported to be inactive on this receptor class (Balasubramaniam et al., 1990; Grundemar et al., 1991; Wahlestedt et al., 1992). Whilc it is certainly too early to claim the existence of possible structural homologies between NPY and $\sigma$ receptor classes, the pattern of in vivo interactions observed in the present study and those of others (Monnet et al., 1990a,b) raises interesting possibilities as the various NPY receptor subtypes (Rimland et al., 1991; Herzog et al., 1992; Larhammar et al., 1992), and likely the $\sigma 1$ site (Itzhak and Stein, 1991 b; Itzak et al., 1991; Bowen at al., 1992; Quirion et al., 1992) could all belong to the G-protein-coupled rhodopsin receptor superfamily.

In summary, the present study revealed the existence of in vivo interactions between certain NPY-related peptides and ${ }^{3} \mathrm{H}$ (+)SKF 10,047/ $\sigma$ labeling in the mouse hippocampus. Further studies are currently in progress to determine the mechanism(s) 
responsible for these interactions and the possible functional significance of these findings.

\section{References}

Balasubramaniam A, Sheriff S, Rigel DF, Fisher JE (1990) Characterization of neuropeptide $Y$ binding sites in rat cardiac ventricular membranes. Peptides 11:545-550.

Bowen WD, Feinstein G, Orringer JS (1992) Sigma-1 and sigma-2 binding sites of rat kidney. Soc Neurosci Abstr 18:456.

Chavkin C (1990) The sigma enigma: biochemical and functional correlates emerge for the haloperidol sensitive sigma binding site. Trends Pharmacol Sci 11:213-215.

Connick JH, Addae JI, Nicholson CD, Stone TW (1992) The $\sigma$ ligand 1,3-di-o-tolylguanidine depresses amino acid-induced excitation nonselectively in rat brain. Eur J Pharmacol 214:169-173.

Connor MA, Chavkin C (1991) Focal stimulation of specific pathways in the rat hippocampus causes a reduction in radioligand binding to the haloperidol-sensitive sigma receptor. Exp Brain Res 85:528-536.

Connor MA, Chavkin C (1992) Is the haloperidol-sensitive sigma binding site a receptor for an endogenous neurotranmitter? In: Multiple sigma and PCP receptor ligands: mechanisms for neuromodulation and neuroprotection? (Kamenka JM, Domino EF, eds), pp 201210. Ann Arbor, MI: NPP.

Contreras PC, DiMaggio DA, O'Donohue TL (1987a) An endogenous ligand for the sigma opioid binding site. Synapse 1:57-61.

Contreras PC, Quirion R, Gehlert DR, Contreras ML, O'Donohue TL (1987b) Autoradiographic distribution of non-dopaminergic binding sites labelled by ${ }^{3} \mathrm{H}$-halopcridol in rat brain. Neurosci Lett $75: 133-$ 140 .

Deutsch SI, Weizman A, Goldman ME, Morihisa JM (1988) The sigma receptor: a novel site implicated in psychosis and antipsychotic drug efficacy. Clin Neuropharmacol 11:105-119.

DiPaolo L, Carroll FI, Abraham P, Bai Y, Parham K, Mascarella SW, Zhang X, Wallace P, Walker TM, Bowen WD (1991) N-substituted derivatives of normetazocine: differentiation of sigma 1 and sigma 2 receptors. Soc Neurosci Abstr 15:814.

Dumont Y, Fournier A, St.-Pierre S, Schwartz TW, Quirion R (1990) Differential distribution of neuropeptide $\mathrm{Y} 1$ and $\mathrm{Y} 2$ receptors in the rat brain. Eur J Pharmacol 191:501-503.

Dumont Y, Martel J-C, Fournier A, St.-Pierre S, Quirion R (1992) Neuropeptide $\mathrm{Y}$ and neuropeptide $\mathrm{Y}$ receptor subtypes in brain and peripheral tissues. Prog Neurobiol 38:125-167.

Dumont Y, Fournier A, St.-Pierre S, Quirion R (1993) Comparative characterization and autoradiographic distribution of neuropeptide $Y$ receptor subtypes in the rat brain. J Neurosci 13:73-86.

Ferris CD, Hirsch DJ, Brooks BP, Snyder SH (1991) $\sigma$ Receptors: from molecule to man. J Neurochem 57:729-737.

Ferris RM, Russel A, Topham P (1988) Pharmacological studies suggest that sigma receptors labelled in vivo with $\left[{ }^{3} \mathrm{H}\right](+)$ SKF 10,047 are predominantly of the high affinity type. In: Sigma and phencyclidinelike compounds as molecular probes in biology (Domino EF, Kamenka JM, eds), pp 315-325. Ann Arbor, MI: NPP.

Fuhlendorff J, Gether U, Aakerlund L, Langeland-Johansen N, Thogersen $\mathrm{H}$, Melberg SG, Band-Olsen U, Thastrup O, Schwartz TW (1990) $\left[\mathrm{Leu}^{31}, \mathrm{Pro}^{34}\right]$ neuropeptide $\mathrm{Y}$ : a specific $\mathrm{Y}_{\text {, }}$ receptor agonist. Proc Natl Acad Sci USA 87:1 82-186.

Grundemar L, Wahlestedt C, Reis DJ (1991) Neuropeptide Y acts at an atypical receptor to evoke cardiovascular depression and to inhibit glutamate responsiveness in the brainstem. J Pharmacol Exp I ther 258:633-638.

Gundlach AL, Largent BL, Snyder SH (1986) Autoradiographic localization of $\sigma$-receptor binding sites in guinea pig and rat central nervous system with (+) ${ }^{3} \mathrm{H}-3$-(3-hydroxyphenyl)- $N$-(1-propyl)-piperidine. J Neurosci 6:1757-1770.

Hellewell SB, Bowen WD (1990) A sigma-like binding site in rat pheochromocytoma (PC12) cells: decreased affinity for $(+)$-benzomorphans and lower molecular weight suggest a different sigma receptor from that of guinea pig brain. Brain Res 527:244-253.

Herzog H, Hort YJ, Ball HJ, Hayes J, Shine J, Selbie LA (1992) Cloned human neuropeptide $Y$ receptor couples to two different second messenger systems. Proc Natl Acad Sci USA 89:5794-5798.

Itzhak Y, Stein I (1991a) Sigma binding sites in the brain: an emerging concept for multiple sites and their relevance for psychiatric disorders. Life Sci 47:1073-1081.
Itzhak Y, Stcin I (1991b) Regulation of $\sigma$ receptors and responsiveness to guanine nucleotides following repeated exposure of rats to haloperidol: further evidence for multiple $\sigma$ sites. Brain Res 566:166-172.

Itzhak Y, Stein I, Zhang SH, Kassim CO, Cristante D (1991) Binding of sigma ligands to C57BL/6 mouse brain membranes: effects of monoamine oxidase inhibitors and subcellular distribution studies suggest the existence of sigma receptor subtypes. J Pharmacol Exp Ther 257:141-148.

Junien JL, Leonard BE (1989) Drugs acting on $\sigma$ and phencyclidine receptors: a review of their nature, function and possible therapeutic importance. Clin Neuropharmacol 12:353-374.

Keats AS, Telford J (1964) Narcotic antagonists as analgesics. Clinical aspects. In: Advances in chemistry series, Vol 45, Molecular modification in drug design (Gould RF, ed), pp 170-176. Washington, DC: Amcrican Chemical Society.

Largent BL, Gundlach AL, Snyder SH (1986) Pharmacological and autoradiographic discrimination of sigma and phencyclidine receptor binding sites in brain with $(+)-\left[{ }^{3} \mathrm{H}\right] \mathrm{SKF} 10,047,(+)-\left[{ }^{3} \mathrm{H}\right]-3-[3-\mathrm{hy}-$ droxyphenyl]- $N$-(1-propyl)piperidine and $\left[{ }^{3} \mathrm{H}\right]-1-[1-(2-$ thienyl)cyclohexyl]piperidine. J Pharmacol Exp Ther 238:739-748.

Larhammar D, Blomqvist AG, Yee F, Jazin E, Yoo H, Wahlestedt C (1992) Cloning and functional expression of a human neuropeptide Y/peptide YY receptor of the Y1 type. I Biol Chem 267:1093510938.

Loo P, Braunwalder AF, Williams M, Sills MA (1987) The novel anticonvulsant MK-801 interacts with central phencyclidine recognition sites in rat brain. Eur J Pharmacol 135:261-263.

Lowry OH, Rosebrough NJ, Farr AL, Randall RJ (1951) Protein measurements with the folin phenol reagent. J Biol Chem 193:265275.

Lynch DR, Walker MW, Miller RJ, Snyder SH (1989) Neuropeptide $Y$ receptor binding sites in rat brain: differential localization with [25I] peptide $\mathrm{YY}$ and $\left[{ }^{125} \mathrm{I}\right]$ neuropeptide $\mathrm{Y}$ imply receptor heterogeneity. J Neurosci 9:2607-2619.

Martel JC, St.-Pierre S, Quirion R (1986) Neuropeptide Y receptors in rat brain: autoradiographic localization. Peptides 7:55-60.

Martel JC, Fournier A, St.-Pierre S, Quirion R (1990a) Quantitative autoradiographic distribution of [125 $\mathrm{I}]$ Bolton-Hunter neuropeptide $Y$ receptor binding sites in rat brain. Comparison with [ $\left.{ }^{125} I\right]$ peptide YY receptor sites. Neuroscience 36:255-283.

Martel JC, Fournier A, St.-Pierre S, Dumont Y, Forest M, Quirion R (1990b) Comparative structural requirements of brain neuropeptide $Y$ binding sites and vas deferens neuropeptide $Y$ receptors. Mol Pharmacol 38:494-502.

Martin WR, Eades CE, Thompson JA, Huppler RE (1976) The effects of morphine- and nalorphine-like drugs in the non-dependant and morphine-dependant chronic spinal dog. J Pharmacol Exp Ther 197: 517-532.

McCann DJ, Rabin RA, Rens-Dominiano S, Winter JC (1989) Pencyclidine/SKF-10,047 binding sites: evaluation of function. Pharmacol Biochem Behav 32:87-94.

McLean S, Weber E (1988) Autoradiographic visualization of haloperidol-sensitive sigma receptors in guinea-pig brain. Neuroscience 25:259-269.

McQuiston AR, Colmers WF (1991) Neuropeptide Y (NPY) does not alter postsynaptic NMDA currents in pyramidal neurons of area $\mathrm{CA}_{3}$ of the rat hippocampal slice. Soc Neurosci Abstr 17:975.

Monnet FP, Debonnel G, de Montigny C (1990a) $N$-methyl-D-aspartate-induced neuronal activation is selectively modulated by sigma receptors. Eur J Pharmacol 179:441-445.

Monnet FP, Debonnel G, de Montigny C (1990b) Neuropeptide Y selectively potentiates $N$-methyl-D-aspartate-induced neuronal activation. Eur J Pharmacol 192:207-208.

Monnet FP, Blier P, Debonnel G, de Montigny C (1991) Sigma receptor ligands modulate the NMDA-induced release of ${ }^{3} \mathrm{H}$-norepinephrine in the rat hippocampus. Third IBRO World Congress of Neuroscience P56.36:364.

Monnet FP, Fournicr A, Debonncl G, de Montigny C (1992a) Neuropeptide $\mathrm{Y}$ potentiates selectively the $N$-methyl-D-aspartate response in the rat $\mathrm{CA}_{3}$ dorsal hippocampus. I. Involvement of an atypical neuropeptide $Y$ receptor. J Pharmacol Exp Ther 263:1212-1218.

Monnet FP, Debonnel G, Fournier A, de Montigny C (1992b) Neuropeptide $\mathrm{Y}$ potentiates the $\mathrm{N}$-methyl-D-aspartate response in the $\mathrm{CA}_{3}$ dorsal hippocampus. II. Involvement of a subtype of sigma receptors. J Pharmacol Exp Ther 263:1219-1225 
Monnet FP, Debonnel G, de Montigny C (1992c) In vivo electrophysiological evidence for a selective modulation of $N$-methyl-D-aspartate-induced activation in rat $\mathrm{CA}_{3}$ dorsal hippocampus by sigma ligands. J Pharmacol Exp Ther 179:441-445.

Musacchio JM (1990) The psychotomimetic effects of opiates and the sigma receptor. Neuropsychopharmacology 3:191-200.

Quirion R, DiMaggio DA, French ED, Contreras PC, Shiloach J, Pert CB, Everist H, Pert A, O'Donohue TL (1984) Evidence for an endogenous peptide ligand for the phencyclidine receptor. Peptides 5:967973.

Quirion R, Chicheportiche R, Contreras PC, Johnson KM, Lodge D, Tam SW, Woods JH, Zukin SR (1987) Classification and nomenclature of phencyclidine and sigma receptor sites. Trends Neurosci 10:444-446.

Quirion R, Martel J-C, Dumont Y, Cadieux A, Jolicoeur F, St.-Pierre S, Fournier A (1990) Neuropeptide Y receptors: autoradiographic distribution in the brain and structure-activity relationships. Ann NY Acad Sci 611:58-72.

Quirion R, Mount H, Chaudieu I, Dumont Y, Boksa P (1991) Neuropeptide $Y$, polypeptide $Y Y$, phencyclidine and sigma related agents: any relationships? In: NMDA receptor related agents: biochemistry, pharmacology and behavior (Kameyama T, Nabeshima T, Domino EF, eds), pp 203-210. Ann Arbor, MI: NPP.

Quirion R, Bowen W, Itzhak Y, Junien JL, Musacchio JM, Rothman RB, Su TP, Tam SW, Taylor DP (1992) A proposal for the classification of sigma binding sites. Trends Pharmacol Sci 13:85-86.

Rimland J, Sin W, Sweetnan P, Saijoh K, Nestler EJ, Duman DS (1991) Sequence and expression of a neuropeptide $Y$ receptor cDNA. Mol Pharmacol 40:869-875.

Rioux F, Quirion R, St.-Pierre S, Regoli D, Jolicoeur FB, Belanger F, Barbeau A (1981) The hypotensive effect of centrally administered neurotensin in rats. Eur J Pharmacol 69:241-247.

Rivière PJM, Pascaud X, Junien JL, Porreca F (1990) Neuropeptide $\mathrm{Y}$ and JO 1784, a selective $\sigma$ ligand, alter intestinal ion transport through a common, haloperidol-sensitive site. Eur J Pharmacol 187: $557-559$.

Roman FJ, Pascaud XP, Duffy O, Vauche D, Martin B, Junien JL (1989) Neuropeptide $Y$ and peptide $Y Y$ interact with rat brain sigma and PCP binding sites. Eur J Pharmacol 174:301-302.

Roman FJ, Pascaud X, Duffy O, Vauche D, Junien JL (1991) Modulation by neuropeptide $Y$ and peptide $Y Y$ of NMDA effects in rat hippocampal slices. Role of sigma receptors. In: NMDA receptor related agents: biochemistry, pharmacology and bchavior (Kamcnyama T, Nabeshima T, Domino EF, eds), pp 211-218. Ann Arbor, MI: NPP.

Snyder SH, Largent BL (1989) Receptor mechanisms in antipsychotic drug action: focus on sigma receptors. J Neuropsychiatry 1:7-15.

St.-Pierre S, Lalonde JM, Gendreau M, Quirion R, Regoli D, Rioux F (1981) Synthesis of peptides by the solid-phase method 6. Neurotensin, fragments and analogues. J Med Chem 24:370-376.

Su TP (1982) Evidence for s opioid receptor binding of ${ }^{3} \mathrm{H}-\mathrm{SKF} 10,047$ to etorphine-inaccessible sites in guinea pig brain. J Pharmacol Exp Ther 223:284-290.

Su TP (1986) HR375: a potential antipsychotic drug that interacts with dopamine D2 receptor and $\sigma$ receptor in the brain. Neurosci Lett $71: 224-228$

Su TP (1991) $\sigma$ receptors: putative links between nervous, endocrine and immune systems. Eur J Biochem 200:633-642.
Su TP, Vaupel DB (1988) Further characterization of an endogenous ligand ("sigmaphin") for sigma receptors in the brain. Soc Neurosci Abstr 14:545.

Su TP, Weissman AD, Yeh S-Y (1986) Endogenous ligands for sigma opioid receptors in the brain ("sigmaphin"): evidence from binding assays. Life Sci 38:2199-2210.

Su TP, Wu XZ, Spivak CE, London ED, Bell JA (1991) Sigma ${ }_{1}$ and sigma $_{2}$ receptors in NCB-20 cells: evidence from electrophysiological and binding studies. In: NMDA receptor related agents: biochemistry, pharmacology and behavior (Kamenyama T, Nabeshima T, Domino EF, eds), pp 211-218. Ann Arbor, MI: NPP.

Tam SW, Cook L (1984) $\sigma$-Opiates and certain antipsychotic drugs mutually inhibit $(+)-\left[{ }^{3} \mathrm{H}\right]$ haloperidol binding in guinea pig brain membranes. Proc Natl Acad Sci USA 81:5618-5621.

Tam SW, Mitchell KN (1991) Neuropeptide Y and peptide YY do not bind to brain $\sigma$ and phencyclidine binding sites. Eur J Pharmacol 193:121-122.

Tan SW, Steinfels GF, Cook L (1988) Biochemical and behavioral aspects of sigma and phencyclidine receptors: similarities and differences. In: Sigma and phencyclidine-like compounds as molecular probes in biology (Domino EF, Kamenka JM, eds), pp 383-396. Ann Arbor, MI: NPP

Taylor DP, Dekleva J (1987) Potential antipsychotic BMY 14802 selectively binds to sigma sites. Drug Dev Res 11:65-70.

Vaupel DB (1983) Naltrexone fails to antagonize the effects of PCP and SKF 10,047 in the dog. Eur J Pharmacol 92:269-274.

Vilner BJ, Bowen WD (1992) Characterization of sigma-like binding sites of NB41A3, S-20Y, and N1E-115 neuroblastomas, C6 glioma, and NG108-15 neuroblastoma-glioma hybrid cells: further evidence for sigma-2 receptors. In: Multiple sigma and PCP receptor ligands: mechanisms for neuromodulation and neuroprotection? (Kamenka JM, Domino EF, eds), pp 341-353. Ann Arbor, MI: NPP.

Wahlestedt C, Yanaihara N, Hakanson R (1986) Evidence for different pre-and post-junctional receptors for neuropeptide $Y$ and related peptides. Regul Peptides 13:307-318.

Wahlestedt C, Grundemar L, Hakanson R, Heilig M, Shen GH, Zukowska-Grojec Z, Reis DJ (1990) Neuropeptide Y receptor subtypes, $Y_{1}$ and $Y_{2}$. Ann NY Acad Sci 611:7-26.

Wahlestedt C, Regunathan S, Reis DJ (1992) Identification of cultured cells selectively expressing $Y_{1^{-}}, Y_{2^{-}}$, or $Y_{3}$-type receptors for neuropeptide Y/peptide YY. Life Sci 50:PL7-PL12.

Walker JM, Bowen WD, Walker FO, Matsumoto RR, De Costa B, Rice KC (1990) Sigma reccptors: biology and function. Pharmacol Rev 42:355-402.

Weissman AD, Su TP, Hedreen JC, London ED (1988) Sigma receptors in post-mortem human brains. J Pharmacol Exp Ther 247:2933.

Weissman AD, Broussolle EP, London ED (1990) In vivo binding of ${ }^{3} \mathrm{H}$-D- $N$-allylnormetazocine and $\left[{ }^{3} \mathrm{H}\right]$ haloperidol to sigma receptors in the mouse brain. J Chem Neuroanat 3:347-354.

Wilson DA, O'Neill JT, Said SI, Traystman RJ (1981) Vasoactive intestinal polypeptide and the cerebral circulation. Circ Res 48:138148 .

Zhang AZ, Mitchell KN, Cook L, Tam SW (1988) Human endogenous brain ligands for sigma and phencyclidine receptors. In: Sigma and phencyclidine-like compounds as molecular probes in biology (Domino EF, Kamcnka JM, eds), pp 335-343. Ann Arbor, MI: NPP. 